Hanna Ratuszna ${ }^{1}$

Uniwersytet im. Mikołaja Kopernika w Toruniu

DOI: https://doi.org/10.26881/jsr.2021.16.11

\title{
„DUCH NOWOCZESNOŚCI” - W KRĘGU BAJEK JÓZEFA JANKOWSKIEGO
}

\section{Artystyczne tęsknoty}

W artykule Zenona Przesmyckiego pt. Odrodzenie bajki, opublikowanym w 1902 r. w „Chimerze”, pojawia się interesująca refleksja o literaturze, jej zadaniach, wyzwaniach wobec współczesności: „artysta dzisiejszy - jak czytamy duszę tylko na jaw wydobyć pragnie, odsłonić najtajniejsze jej zakąty, dać wyraz najgłębszym jej zadrgnieniom" (Przesmycki 1967, s. 210).

Bajka literacka, bo o niej mowa, zajęła w nowej perspektywie opisu świata ważne miejsce. Przede wszystkim wydobyła na jaw ukryte konflikty, napięcia współczesności, interpretowała rzeczywistość. Modernistyczna refleksja o codzienności odbywała się w atmosferze sporów o wartości, wśród których ważne miejsce zajęło zagadnienie ,piękna estetycznego” (Podraza-Kwiatkowska 1977, s. 83). Krytycy literaccy, filozofowie (m.in. E. Abramowski, I. Matuszewski, M. Zdziechowski), dostrzegli w sztuce obecność „wrażenia estetycznego” (Podraza-Kwiatkowska 1977, s. 88), które sprzyjało refleksji o nieskończoności. Marian Zdziechowski (1977, s. 89) pisał: „Jednym więc z głównych czynników twórczości artystycznej jest żądza nieskończoności [...]”. Akt twórczy w sztuce modernistów wynikał z doświadczenia wewnętrznego; ważne były zarówno gest kreatora, jak i wpisana w dzieło myśl. Sztuka interpretowała świat, tworzyła obrazy, gesty, nadawała słowom nowe znaczenia, miała w dużej mierze symboliczny charakter. Rainer Maria Rilke pisał w 1898 r. w „Ver Sacrum”: „sztuka jest poglądem na życie, podobnie prawie jak religia i nauka" (Rilke 1898, s. 411). Sztuka była dla niego równoznaczna $\mathrm{z}$ istnieniem, akt twórczy stał się bliski aktowi narodzin: „Chciałoby się więc dzieło sztuki objaśnić jako wyznanie płynące z największej głębi [...], które oddzielone od swego nosiciela może istnieć samodzielnie" (Rilke 1898, s. 412). Zagadnienia dotyczące aktów twórczych, duszy artysty, refleksji o nieskończoności współtworzyły nurt dyskusji estetycz-

${ }^{1}$ hanna.ratuszna@umk.pl, https://orcid.org/0000-0002-7544-3581 
nej, która wpisywała się tematycznie w dyskurs o nowoczesności. Jej istotnym elementem stała się negacja pojęcia sztuki zaangażowanej, społecznego kontekstu działań artystycznych. Rilke łączył w swoich poszukiwaniach typowe dla ekspresjonisty spojrzenie na „duchową naturę świata” z dozą nieufności wobec zmieniającej się rzeczywistości. Sztuka słowa, obrazu była dla niego grą interpretacji, w której objawiona zostaje nowa jakość, a nawet nowa rzeczywistość. Jak pisał: „z każdym dziełem sztuki pojawia się coś Nowego, jakaś nowa rzecz przybywa na świat" (Rilke 1898, s. 412). Podobny kontekst pojawia się w wypowiedziach Stanisława Przybyszewskiego, polskiego modernisty, który - tak jak inni krytycy, orędownicy nowej sztuki, np. Ignacy Matuszewski - postrzegał zagadnienie nowoczesności w sztuce w perspektywie aporii sfery zewnętrznej i wewnętrznej:

A jeżeli twórca dotychczasowy kładł nacisk na świadome, logiczne łączenie myśli [...], operował rzeczami zewnętrznymi, które uważał za coś absolutnego we fałszywym pojęciu, że ,zewnątrz” i „,wewnątrz” zupełnie się pokrywa, to przeciwnie: przedstawiciel nowej sztuki całkiem odwraca się od tego „zewnątrz” jako od rzeczy przypadkowej, zmiennej, wyłania się w siebie, chwyta w swej duszy rzeczy słowem nie ujęte (Przybyszewski 1977, s. 403).

Perspektywa ta pojawiła się wcześniej w twórczości francuskich symbolistów, m.in. Stephena Mallarmé, który m.in. w utworze Okna konfrontował marzenie z rzeczywistością:

Pierzcham - i wszystkich okien czepiam się przebojem,

Gdzie do życia się tyłem zwracam, i z zachwytem,

$\mathrm{W}$ ich szybach, zmytych rosy wiekuistej zdrojem,

Nieskończoności czystym ozłoconych świtem,

Przeglądam się - i nagle widzę się aniołem!

(Mallarme 1900, s. 1)

Marzenie poetyckie jest nadrzeczywistością, która „rodzi się w bezruchu” (nie jest poparta żadnym działaniem). Wyobraźnia stwarza wówczas miraże, jej istotę wyjaśnia symbolika okna, w którym „zewnętrze” jest skonfrontowane z tym, co „wewnętrzne" - przy czym obraz wnętrza, który odbija się w oknie, jest odwrócony, zniekształcony, inny ${ }^{2}$. Konfrontacja „wnętrza” i ,zewnętrza”

${ }^{2}$ Georges Poulet (1977, s. 228) interpretował wiersz następująco: „Ideał istniejący poprzez własne marzenie sam jest jedynie marzeniem, marzeniem absurdalnym, może bowiem istnieć tylko na zasadzie niedorzecznego kontrastu z odwrotną rzeczywistością, która go zaprzecza i którą on zaprzecza". 
opiera się na zasadzie negacji: to, co „zewnętrzne”, nie jest tym, co „wewnętrzne” - taka jest „egzystencja” marzenia, które w istocie nie jest rzeczywistością. Sztuka modernizmu, literatura, w szczególności bajka, baśń, podejmują temat istnienia, które „przeradza się w byt” (Dasein), funkcjonuje w marzeniu. Bajkowa rzeczywistość, nawet ta oparta na tradycji ludowej, nadaje marzeniu istotne znaczenie, „urealnia” je. Realność nie oznacza jednak istnienia, uobecnienia „zewnętrzności”, lecz wskazuje na obecność marzenia, które „egzystuje” w perspektywie konfrontacji tego, co „zewnętrzne”, z tym, co „wewnętrzne”.

Bajki, przypowiastki ze względu na niektóre cechy gatunkowe - alegoryczność, magiczny kostium, dyskursywność, obecność puent - stanowiły cenny kontekst w zainicjowanym u progu współczesności dyskursie estetycznym (sporze o piękno). Bajka, na co zwrócił uwagę Przesmycki, zyskała nową postać, stała się hybrydyczna (forma, treść), co wiązało się z ogólnym rozumieniem roli gatunków literackich. Warto przypomnieć, że moderniści odrzucili klasyczny podział na rodzaje i gatunki literackie; problem „samodzielności gatunkowej” utworów nie był dla nich istotny (por. Głowiński 1997, s. 117). Bajki literackie w okresie modernizmu odsłoniły tajniki ludzkiej psychiki, ilustrowały ważne idee filozoficzne (np. egzystencjalizm, solipsyzm, finalizm; por. bajki Oskara Wilde'a), prezentowały koncepcje estetyczne (por. Poematy barbarzyńskie czy Poematy antyczne Laconte'a de Lisle'a). W utworach autorzy posługiwali się także kostiumami zwierzęcymi, sięgali po bajkę lafontaine'owską (ciekawym przykładem jest Pantera czarna Laconte'a de Lisle'a).

Typ bajki ilustrującej idee filozoficzne, odsłaniającej głębie (i niepokoje) człowieczego świata realizował także Józef Jankowski - pisarz i zarazem aktor, „człowiek teatru”, współpracownik Zielonego Balonika, przyjaciel cenionego bajkopisarza Jana Lemańskiego. W jego dorobku artystycznym, obok opowiadań, nowel i humoresek, ważną rolę odgrywały zarówno wierszowane bajki zwierzęce, jak i bajki o nieskończoności, które przeważnie odkrywały „metafizyczną głębię istnienia”. Wśród nowel pojawiły się także utwory bajkowe, w których autor wykorzystywał ludowe wątki, np. opowieści o diable, motyw zwierciadła czy wątek o tańczących bucikach. Twórczość Jankowskiego interesująco ilustrowała proces przenikania, adaptacji literackiej wątków zaczerpniętych z tradycji ludowej, odsłoniła również specyfikę (i różnorodność) literackich bajek powstałych w epoce fin de siècle'u. Jankowski próbował pogodzić w nich ważne kwestie dotyczące pojęcia nowoczesności, które znalazły się u podstaw modernistycznej świadomości. Nowoczesność, którą promował pisarz, nie oznaczała zerwania $\mathrm{z}$ tradycją, utrwalonymi w kulturze wartościami, była jednak pełną napięć konfrontacją przeszłości z teraźniejszością (codziennością). Dziedzictwo przeszłości zyskało wówczas nowe znaczenie, stanowiło punkt odniesienia dla współczesności. Myślenie o nowoczesności jako pewnej strategii artystycznej stało się alternatywą dla pogrążonego w chaosie świata. Dla Charles'a Baudela- 
ire'a sztuka nowoczesna odzwierciedlała dynamikę życia: „Sztuka nowoczesna zatem uwidacznia to, co przemijające. Udaje jej się to po pierwsze dzięki temu, iż ujmuje dynamikę życia, a nie statyczny obraz rzeczywistości, i że czyni tak nie przez to, że odzwierciedla świat w ruchu, lecz że sama staje się ruchomym zwierciadłem" (Nycz 1998, s. 82).

Józef Jankowski pojmował nowoczesność w bardzo podobny sposób - jako nieuchronny etap rozwoju, w którym sztuka stawała się elementem postępu, kształtowała się w blasku idei nauki. Sztuka poszukiwała wpisanych w kulturę episteme (Foucault 2006, s. 156) ${ }^{3}$, tropiła ich znaczenia, była zatem swoistym medium, które sprzyjało nowej interpretacji, konstruowaniu nowoczesnej świadomości. Sam postęp oznaczał m.in. emancypację jednostek ${ }^{4}$ i społeczeństw, stanowił wyraz dążeń w procesie zdobywania samoświadomości, porządkowania chaosu świata. Jankowski traktował bajkę jako gatunek, który - jak twierdził w cytowanym eseju Zenon Przesmycki - został „wpisany w dziedzinę sztuki”:

Tylko bowiem dzieła, jako uzewnętrznienie duszy autora, nie zaś tworzona ad hoc, ze świadomym czy nieświadomym podporządkowaniem tej duszy jakimś wzorom, regułom czy nawyknieniom, na nazwę dzieł sztuki zasługują (Przesmycki 1967, s. 209).

Bajki tworzyły więc w dyskursie nowoczesności ważny kontrapunkt: inicjowały refleksję o roli kartezjańskiej podmiotowości, w szczególności zaś - nowożytnej koncepcji antropologicznej pojęcia duszy.

\section{Odsłona pierwsza: bajki o nieskończoności}

Anna Czabanowska-Wróbel (1996, s. 32) zwraca uwagę na rolę baśniowego światopoglądu, który kształtuje refleksję o człowieku schyłku XIX w. Opowieść o duszy, przybrana w baśniowy kostium, zyskuje nowe znaczenie, odsłania tęsknoty metafizyczne, pozostaje jednak w cieniu dwóch fenomenów: miłości i śmierci. Śmierć traci swój finalny wymiar, jest zwykle procesem przejściem, mroczną krainą (a zatem miejscem), bywa także osobą (personifikacje śmierci), którą można niekiedy przechytrzyć. Refleksja o niej wpisuje się w obecny w literaturze od dawna nurt meditatio mortis, niekiedy jednak wskazuje na triumf śmierci. Inne znaczenie zyskuje dyskurs o miłości, kształtujący się najczęściej w cieniu utraty, poczucia pustki, pragnień, które nie zostaną spełnione. Pojawia-

${ }^{3}$ M. Foucault wyróżnił trzy „typy” episteme, którym odpowiadają poszczególne etapy rozwoju kulturalnego: renesans, okres klasyczny oraz przełom XIX i XX w.

${ }^{4}$ Jest to taki stosunek do świata, w którym człowiek nadaje sobie władzę samostanowienia - o czym pisał m.in. A. Renaut (2003, s. 31). 
jące się przeszkody należy pokonać, by poczuć twórczą potęgę miłości; myśl ta inicjuje etapy duchowego wzrastania (rola bajkowej puenty). Jankowski w swojej twórczości - w bajkach o nieskończoności, które nie zostały nigdy w całości wydane (większość z nich pozostała w rękopisach zachowanych w archiwum pisarza $^{5}$ ) - prezentuje taki właśnie kontekst opowieści. Ujawnia odwieczne pragnienia człowieka: przekraczania granic poznawczych, tropienia tajemnic natury. Miłość i śmierć stymulują poznanie, wyznaczają granicę (śmierć) i zarazem pozwalają ją przekroczyć (miłość); refleksja o nich stwarza iluzje, budzi lęk, nadaje sens wszelkim poszukiwaniom. W opowieści pt. Atom pojawia się melancholijna dygresja o nieskończoności w perspektywie pascalowskiej, a zatem poświęcona nieskończoności światów ukrytych w obrębie cząstki atomu (Pascal b.r., s. 62). Pascal wyróżnił dwa „rodzaje” Ja: Ja wyobrażone i Ja realne. Ja wyobrażone jest nieuchwytne, ujawnia się w „prześwitach” działań, grach, zabawach (Poulet 1974, s. 142); Ja realne inicjuje pragnienie ucieczki, przekraczania granic właśnie w kierunku Ja wyobrażonego. Komentujący pisma Pascala Georges Poulet nazywa to działanie twórczością á rebours:

Stwarzamy siebie w końcu jedynie po to, by przed sobą uciekać; lub raczej zdeprawowana myśl ludzka, niezdolna tworzyć prawdziwe istnienia ani „podtrzymywać teraźniejszości”, ośmiela się wzmacniać i odtwarzać siebie poprzez ruch odwrotny, przez tworzenie niebytu, przez nieograniczone mnożenie przedmiotów swojego zainteresowania (Poulet 1974, s. 143).

Jankowski tworzy w bajkach iluzję istnienia w perspektywie wieczności $J a$ wyobrażonego; głębia poznania odsłania nowy wymiar trwania, inne znaczenie chwili. Utwór pozornie zachowuje formę bajki - opowieści kierowanej do dziecięcego adresata:

Opowiem ci bajkę, kochanie

Niech światłem dla duszy się stanie

(J.J. Atom, s. 1) .

Jego wierszowana postać stanowi interesujące nawiązanie do tradycji bajek oświeceniowych realizujących zasadę docere - delectare, choć podtytuł Poezja ilości wskazuje na jeszcze inny trop. Ważne okazuje się spojrzenie wartościują-

${ }^{5}$ Dostępne na stronach Biblioteki Narodowej w systemie POLONA.

${ }^{6}$ Omawiane bajki oznaczam inicjałem autora, tytułem i nrem strony; szczegółowe opisy bibliograficzne w wykazie literatury podmiotu. 
ce; nieskończoność jawi się w utworze jako „coś niepoliczalnego”, nie można jednak także wykluczyć ,znaczenia intensywności”?:

Pytasz: jak duży ten atom?

Hej, ho, by móc go ująć przez obrazy,

powiększmy wszystko sto razy"

(J.J. Atom, s. 1).

Zwielokrotniona rzeczywistość (proces powiększania zostanie powtórzony kilka razy) pozwala dostrzec atom, równocześnie jednak uzmysławia ogrom, nieskończoność świata:

Atom się jeszcze składa $\mathrm{z}$ elektronów promiennych swoich członów, a każdy z nich, pełen blasku, Jest tem w stosunku do ziarnka piasku Czem ziarnko piasku, z siłami wszystkiemi, Co do wielkości - w stosunku, do ziemi (J.J. Atom, s. 4).

Refleksja o nieskończoności tylko pozornie traci metafizyczny wymiar, opiera się na analizie relacji tego, co znane i niepoznawalne (J.J. Atom, s. 3). Nieskończoność - podobnie jak rozumieli ją romantycy: „Nigdzie to, co nieskończone, nie występuje jako nieskończone, jest obecne wszędzie, ale tylko w przedmiocie" (Schelling 1983, s. 88) - pochłania poszczególne istnienia. Myśl o tym procesie budzi fascynację (tremendum fascinans). W bajce Jankowskiego brakuje wyrazistych kreacji bohaterów (podmiotów nieskończoności); choć punktem odniesienia staje się atom, ważniejsza okazuje się refleksja poznawcza - opowieść o tym, jaki ogrom kryje w sobie świat. Atom - rozpoznany i opisany przez badaczy minionych epok - jest sam w sobie odrębnym światem. Nieskończoność ma więc w opowieści ostatecznie wymiar ontologiczny, jest w pełni związana z istnieniem, wpisana w jego ,przemiany”. W odautorskim przypisie do utworu pojawia się nazwisko znanego botanika i matematyka norweskiego Carla Størmera (1974-1957), badacza zórz polarnych, reakcji cząstek naładowanych w polach magnetycznych. Jankowski przywołuje jego opublikowane w Paryżu w 1929 r. dzieło L'espace l'atomic, w którym pojawia się informacja o budowie atomu, zjawisku elektryczności: ,promiennych członach, pełnych blasku” (J.J. Atom, s. 4). Badacz ten był ceniony także jako fotograf Aurora Borealis; dokumentował niezwykłe zjawisko od 1909 r., w publikacjach poświęconych energii atomu nawiązywał do odkryć

${ }^{7}$ E. Levinas wyróżnia pojęcie nieskończoności intensywnej pojmowanej w perspektywie doskonałości istnienia (por. Krajewski 2009, k. 1202). 
matematycznych Henriego Poincaré (rachunek różniczkowy). Utwór o atomie ma zatem kilka istotnych znaczeń; jest utrzymaną w konwencji opowieści dla dziecka bajką: „Śpij słodko, ukołysany elektronową zwrotką” (J.J. Atom, s. 4), stanowi także inspirujący przyczynek do refleksji o istnieniu. Rozważania o atomie pozwalają zrozumieć rolę człowieka w „teatrze świata”, jego samotność, zagubienie w bezkresie.

Podobny obraz pojawia się w utworze pt. Mitość gwiazd, nawiązującym do naukowych teorii Johna Plasketta, który w 1913 r. zbudował 183-centymetrowy reflektor służący do badania tzw. gwiazd podwójnych i przestrzeni międzygwiezdnych. Wynalazek ten umożliwił nowe, wnikliwsze obserwacje nieba. U schyłku XIX w. obawiano się katastrof w wymiarze kosmicznym; obserwacje nieba i motyw podróży w gwiezdne przestrzenie były bardzo popularne (por. np. trylogię księżycową Jerzego Żuławskiego). Poetycka opowieść Jankowskiego o możliwościach poznawczych człowieka pozwala odsłonić kosmiczny ład, ukryty rytm nieskończoności natury, który charakteryzuje najpełniej (jak w ustaleniach Empedoklesa) siła Erosa: „Gwiazda ta śliczna przed trzystu wiekami [...] / Miłości słodkie przeczuwając brzemię / Wzrok swój promienny rzuciła na ziemię" (J.J. Miłość gwiazdy). Człowiek pragnie bowiem - jaki pisał inny poeta „Nieskończoność zmieścić w dłoni małej / Wieczność poznać w ciągu godziny” (Blake 1992, s. 187). Refleksja o gwieździe (J.J. Miłość gwiazdy, s. 12) pozwala zrozumieć nieprzerwany upływ czasu, potęgę natury, która jest wiekuista, rytmiczna (w swej zmienności). Blask gwiazdy był obecny w czasach świetności Babilonu (jak wiadomo, Asyria, Babilonia, Mezopotamia to historyczne krainy, zamieszkiwane przez ludność, która kultywowała tradycje obserwacji nieba, czego odbicie można odnaleźć w wierzeniach (por. rolę bóstw, m.in. Marduka czy Gilgamesza, który był bohaterem solarnym ${ }^{8}$ ); dzięki „odkryciom uczonego kanadyjskiego" można go podziwiać także współcześnie. Nieskończoność zostaje w tym przypadku przedstawiona jako wieczne trwanie, niezmienność (choć natura zmienia cyklicznie swoje oblicze). Gwiazdy, odwieczne przewodniczki człowieka (por. Boska Komedia Dantego), symbolizują w utworze Jankowskiego ludzkie tęsknoty poznawcze, pragnienia. Odkrycie teleskopu przybliża do tajemnicy natury, stanowi wyraz triumfu ludzkiego rozumu: „Na uświęcenie gwiazd wiecznej miłości / Na obalenie Czasu nad nią włości” (J.J. Miłość gwiaz$d y$, s. 12).

Bajki Jankowskiego odsłaniają metafizyczną głębię; podobnie jak w twórczości Jerzego Żuławskiego (por. np. Bajka o człowieku szczęśliwym z 1906 r.) przyjmują także niekiedy postać eseju o istnieniu - por. Piękna bajka o kanałach Marsa, w którym pragnienia, wyobrażenia przenikają smutną, przybraną w kostium melancholii, prawdę o rzeczywistym świecie. W utworze tym, podobnie

${ }^{8}$ Fragmenty Eposu o Gilgameszu tłumaczył m.in. Antoni Lange. 
jak w poprzednich, dominuje naukowy temat. Mars nie jest już tylko „czerwoną planetą", która świeci na niebie wśród innych - odbitym blaskiem. Teleskopy pozwalają obserwować jej kształt, atmosferę. Bajka ta, przygotowana jako pogadanka radiowa (słuchowisko), wyraża- jak można sądzić - istotną dla artysty prawdę, którą określają słowa: „Rzeczywistość nauki piękniejsza od marzenia” (J.J., Piękna bajka o kanałach Marsa, s. 17).

Naukowy charakter bajki przeczy niejako tradycji tego typu opowieści, czego świadectwem są odwołania do odkryć takich badaczy, jak James Sliper, który w 1914 r. za pomocą spektroskopu dostrzegł obecność pary wodnej na Marsie, oraz Giovanni Schiaparelli - mediolański uczony, inicjator dyskusji na temat kanałów obecnych na tej planecie. Opowieść o historii odkryć, jej mitologicznych i literackich „obrazach” uwarunkowanych w kulturze ${ }^{9}$ stała się podstawą dywagacji o samotności człowieka w kosmosie. Jankowski zwrócił także uwagę na spekulacje badaczy w sprawie życia na Marsie, którzy - jak to zwykle bywa bronili tezy o istnieniu Marsjan (m.in. Perciwal Lowell ${ }^{10}$ ) lub jej przeczyli (Arthur Evans $\left.{ }^{11}\right)$. Istotnym punktem odniesienia w prezentowanej opowieści okazała się teza o „tyranii rzeczy widzianych” (J.J, Piękna bajka o kanałach Marsa, s. 17). Jankowski wspomniał o eksperymencie amerykańskich uczonych, którzy przedstawili dzieciom w wieku 11-14 lat fotografię Marsa z zaznaczonymi ciemnymi obszarami. Dzieci natychmiast narysowały kanały odpowiadające tym, które przez szkła teleskopu obserwował Lowell. Amerykański uczony wierzył, że: „Reszta planety byłaby skazana niewątpliwie na śmierć z posuchy i pragnienia, gdyby nie zaradność genialna Marsjan [...], która urządziła gigantyczne dzieło sztucznego nawadniania planety" (J.J, Piękna bajka o kanałach Marsa, s. 11).

Doświadczenie pokazało, jak bardzo ludzie żyjący na Ziemi pragną odnaleźć ślady innego życia w kosmosie. Romantyczne i neoromantyczne tęsknoty, poczucie samotności, uwięzienia w świecie „tu i teraz” znalazły doskonałe dopełnienie w teorii na temat obecności życia na Marsie. Naukowa opowieść przerodziła się w bajkową narrację; wątpliwe hipotezy uczonych porównano do dziecięcych marzeń, w których nie brakuje także ironii: „W kanałach Marsa płynął - jak rzekł dowcipniś - tylko atrament uczonych" (J.J, Piękna bajka o kanałach Marsa, s. 17). Słowo „bajka” („piękna bajka”), użyte w tytule, miało przede wszystkim ironiczny charakter - nie oznaczało przynależności gatunkowej, wskazywało raczej na potoczne znaczenie: „bujda”, „,bajanie”, „snucie domysłów”. Utwór ten można jednak rozpatrywać wraz z „,bajkami o nieskończoności”.

${ }^{9}$ Jankowski opowiada o wielkości planety, jej odległości od Ziemi, wspomina także o księżycach, które nazwano w nawiązaniu do mitologii: Dejmos i Fobos (Groza i Strach) por. J.J., Piękna bajka o kanałach Marsa, s. 2.

${ }^{10}$ Perciwall Lowell (1855-1916) - astronom amator, matematyk amerykański.

${ }^{11}$ Arthur Evans (1851-1941) - archeolog, badacz życia kultur prehistorycznych. 
Podobnie jak one ukazuje bowiem rolę ludzkiego umysłu, tęsknoty za czymś odległym, pragnienie przekraczania granic. Jankowski znalazł w bajkowej formule, która przyjmowała w jego twórczości hybrydyczną postać, antidotum na modernistyczne lęki. Wśród nich ważne miejsce zajmował odwieczny lęk przed śmiercią i samotnością. W licznych utworach ukazujących bohaterów „wydanych na pastwę życia" (por. twórczość Stanisława Przybyszewskiego, Marii Komornickiej, Jerzego Żuławskiego, Kazimierza Przerwy Tetmajera) dominuje portret „galernika”, obecny m.in. w poezji Tadeusza Micińskiego: „Z bram czarnych idę Babilonu, z ruin... wracam w mych więzień kurytarze. I to wszak darem z Twojej ręki” (Miciński 1995, s. 34). Bajki Jankowskiego modyfikowały ten portret: obłaskawiały lęki, ukazywały inne przymioty człowieczego ducha, potęgę rozumu.

\section{Odsłona druga: theatrum mundi, czyli „opowieści niezwykłe”}

Józef Jankowski jako aktor doskonale rozumiał świat sceny. Dał temu wyraz m.in. w artykułach poświęconych wystąpieniom japońskiej trupy Otojirō Kawakamiego (Osiński 1998, s. 134). W 1902 r. trupa ta - ze słynną gejszą Saddą Yako - zaprezentowała się publiczności w Polsce: w Warszawie, Łodzi, Krakowie. Jankowski napisał wówczas na podstawie obejrzanego przedstawienia sztukę pt. Kesa. Wykazał się intuicją artystyczną i znajomością reguł funkcjonowania teatru japońskiego. W jego sztuce nie brakuje śpiewnych monologów, wystąpień kantora oraz sceny mimicznej, w której aktorzy popełniają samobójstwo. Utwór stanowi reinterpretację popularnej sztuki Gejsza i rycerz, granej przez trupę Kawakamiego. Jankowski - dzięki licznym podróżom (m.in. do Paryża, Monachium) i przyjaźni z Feliksem Jasieńskim, „krakowskim Japończykiem" - wcześnie uległ wpływom literatury i sztuki japońskiej. Analizował zatem przedstawienia teatralne Kawakamiego poprzez pryzmat tańca, gestu. Fascynowała go gra aktorów ukrywających twarz pod maską; najintymniejsze i zarazem najtragiczniejsze treści były wówczas prezentowane w milczeniu, zgodnie z regułami teatru $n \bar{o}$ - dialogi zastąpiła pantomima. Jankowski cenił reguły przedstawienia, publicznej prezentacji treści często intymnych.

Teatr modernistyczny w tym okresie ulegał przeobrażeniom: był „teatrem ogromnym”, jak widział go Wyspiański, „Teatrem - Świątynią”, czy wreszcie „intymnym labiryntem” (por. z T. Micińskim). Jak można sądzić, właśnie estetyka przedstawienia teatralnego, pojęcie piękna, które cenili Japończycy (kategoria $u k i y o-\bar{e})$, znalazły interesujące odniesienie w opowiadaniach, w których dominuje intymna tonacja, a bohaterowie żyją ,na granicy światów”. W zbiorze Historie niezwykte (Jankowski 1928) obok opowieści „,buduarowych”, rozgrywających się w środowisku mieszczańskim, takich jak np. Zwierciadło czy 
Niebezpieczna zabawa, pojawily się powiastki (nowele) nawiązujące do ludowej tradycji, np. Diabet albo jak soltys zbawiat swoją duszę. Jankowski sięga w nich po najbardziej znane wątki ludowe, które służą prezentacji duchowych rozterek, moralnych wyborów bohaterów. W pełnej liryzmu opowieści Zwierciadło o upływającym czasie pozornie nieistotny przedmiot staje się „źródłem ludzkich lęków”, jest „szatańskim majakiem”, odbity w lustrze obraz zapowiada bowiem czas nieszczęść. Jankowski ukazuje w utworze losy bohaterów w skonstruowanym przez siebie „teatrze świata”. Rozpoczyna opowieść od opisu niewiele znaczących zdarzeń, pozbawionych szczegółowego komentarza, gestów. Magicznym rekwizytem, medium poznania, staje się lustro. W nim pojawia się postać demona, przypominającego zmarłego ojca, który zapowiada klęskę bohaterki. Lustro więzi duszę, chwyta spojrzenia, odwraca obraz świata, równocześnie jednak, ze względu na grę spojrzeń (spojrzenie ożywia lustrzaną taflę), energetyzuje przestrzeń, wypełnia ją odbitym blaskiem (blik), tworzy „,wrażenie głębi”. Jankowski wykorzystuje te właśnie właściwości zwierciadła, spojrzenie w lustrzaną taflę inicjuje wędrówkę w głąb siebie, niezwykłe spotkanie z ukrytym w „otchłaniach jaźni” lękiem. W literaturze Młodej Polski lustro staje się symbolem bolesnego rozdwojenia duszy (dusza jako „pole bitwy” dobra ze złem; por. np. twórczość Tadeusza Micińskiego), kłopotów z tożsamością (por. baśń Marii Komornickiej O ojcu i córce). Motyw ten pojawia się również w romantycznych utworach, m.in. w Aurelii Gerarda de Nervala. Michael Foucault, analizując obraz Velasqueza pt. Panny $d$ worskie, w którym lustro ogniskuje spojrzenia, zwrócił uwagę na rolę uwięzionej w obrazie, utajonej perspektywy. Lustro zyskuje dialogiczny charakter, staje się medium ukrytych treści (Foucault 2006, s. 160); w opowiadaniu Jankowskiego uruchamia dyskurs o ludzkim przeznaczeniu, o nieuchronności losu (amor fati).

Głębia obrazu, metafizyczny kontekst funkcjonują także w pełnej ironii historii pt. Diabeł albo jak soltys zbawiat swoją duszę, w której dominuje wątek T 800 T 848 Bajki o diable. W utworze stylizowanym na gadkę (czy przypowiodkę, jak określano gawędę) istotną rolę odgrywa wodzący człowieka na pokuszenie diabeł, który ostatecznie zostaje oszukany (wątek ludowy). Fabuła opowieści nie jest skomplikowana; sołtys, pragnąc zdobyć bogactwo (czyli amerykańskie dolary, przesłane biednej wdowie przez syna), przebiera się za diabła, dodaje sobie odwagi, wypijając butelkę spirytusu, i zakrada się nocą do izby. Podstęp szybko wychodzi na jaw dzięki sprytowi wdowy; bohater broni się wówczas, tłumacząc swoje postępowanie pojawieniem się diabła, który rzekomo namówił go do niecnego procederu wyłudzenia dolarów. Utwór kończy pointa odsłaniająca marną kondycję bohatera; słowo spirytus oznacza ducha - i jak czytamy, jest to duch zaprzaństwa, ,istny diabeł”. Utwór Jankowskiego ironicznie komentuje rzeczywistość, obnaża motywy postępowania osób pozornie szanowanych. Opowieść ma ludyczny charakter; refleksja dotyczy przede wszystkim ludzkiej duszy, która 
„objawia swoją naturę” - tchórzliwą, grzeszną. Wydobyta w dialogu gra słów: spirytus - duch ujawnia prawdziwe motywy działania bohatera: „Ale diabeł nie przyszedł. Zląkł się snać sądów polskich. A może dlatego, że sołtys nie miał w kozie butelki ze spirytusem. Bo wszak diabeł - to zły duch, a spirytus po łacinie - to także duch" (J.J., Diabet albo jak soltys zbawiat swoja duszę, s. 95).

W innej opowieści z tomu Historie niezwykłe, pt. Inwalida, pojawia się ludowy wątek o tańczących trzewiczkach. Motyw tańca, popularny w literaturze, sztuce Młodej Polski, wskazuje w tym przypadku na danse macabre; bohater, porwany za niegodziwe uczynki w taneczny wir, ociera się o śmierć. To niezwykłe doświadczenie stanowi dla niego prawdziwą lekcję pokory, jest ostrzeżeniem przed marnotrawieniem darów ducha. Odmienne znaczenie zyskuje bajkowy wątek w utworze pt. Tajemnica księżycowa, w którym nokturnowa aura opowieści, rozmarzenie bohatera „wskrzeszają uroki bajek Szeherezady” (J.J., Tajemnica księżycowa, s. 89) - czarownych, lecz także naznaczonych śmiercią.

Jankowski wpisuje Historie niezwykle w kontekst opowieści grozy, nawiązuje w ten sposób do romantycznej tradycji, mrocznych tajemnic duszy. W jego utworach wydarzeniom towarzyszy aura niepewności; bohaterowie są przekonani o dominacji duchowej natury świata (,prymat ducha nad materią”), tropią jej ślady, próbują racjonalnie wytłumaczyć niezwykłą obecność. Wpadają jednak często w pułapkę zmysłów, doświadczają obłędu. Historie niezwykłe, przypominające m.in. Niesamowite opowieści Edgara Allana Poe, realizują ważny dla tego właśnie autora postulat: „Człowiek nie ustępowałby aniołom i nie podlegałby wcale śmierci, gdyby nie słabość wątłej jego woli” (Poe 2009, s. 48). Jankowski, analizując ludzkie słabości, unika dydaktyzmu, posługuje się chętnie ironią, jego utwory zyskują niekiedy ludyczny charakter. Gra z czytelnikiem ma romantyczny rodowód - literatura jest w niej „ekspresją ducha”. Japoński ideał kruchego piękna, obecny w utworach, oświetla różnice między światem ciała a światem ducha. Napięcia, które towarzyszą tej często lirycznej opowieści, wyznaczają nowy obszar odniesień - jest nią teatrum mundi. To w nim przeszłość spotyka się ze współczesnością (por. np. utwór Zwierciadło), ludowe prawdy zyskują nowe znaczenie, modny spirytyzm (por. np. Demon spirytyzmu) służy odkrywaniu ludzkiej duchowości. Jankowski, sięgając po bajkowe wątki, eksponuje sylwetkę schyłkowca, dekadenta, marzyciela, artysty. Bajki przybrane w kostium niezwykłości (brakuje tu jednak magii, magicznych przedmiotów, magicznego myślenia; niezwykłość oznacza zawieszenie praw rozumu, królestwo ducha) służą zatem refleksji o współczesności. Zgodnie z poglądami popularnego wówczas francuskiego filozofa i antropologa Teodule'a Ribota - najważniejsza w codziennych dążeniach okazuje się ,zagadka człowieka” (Ribot 1901, s. 34). 


\section{Odsłona ostatnia: bajki zwierzęce}

Ostatnią grupę utworów bajkowych, o których należy wspomnieć, stanowią wierszowane opowieści o zwierzętach, wykorzystujące motywy ludowe. Jankowski nawiązuje w nich do bajek Lafontaine'a - posługuje się postaciami zwierząt $w$ dyskursie metafizycznym. Przedstawieni przez niego bohaterowie okazują się w pełni instynktowni, ukrywają swoją prawdziwą naturę (por. bajka Lis i gęś), lub też w kłótni wymyślają sobie od... ludzi. Przykładowo w bajce pt. Zwierzęta pantera, wyczerpawszy repertuar przekleństw, nazywa w gniewie hienę człowiekiem; mówi do niej: „ty, ty... człowieku”. W bajce Lis i gęś tańczący z gęsią lis marzy o tym, by ją zjeść. Myśli jednak o sobie: ,jam przecież etyczny lis, nie żaden wandal”. Ostatecznie jednak zwierzęca natura zwycięża i jak czytamy, lis „nagle się oblizał i gdzieś w głębi trzew / Szczeknął głucho, zjadliwie... Psiakrew!” (J.J., Bajki i wiersze).

Bajki wierszowane Jankowskiego, podobnie jak utwory Jana Lemańskiego, prezentują odwróconą (odbitą w lustrze ironii) perspektywę: nie ukazują przywar zwierząt, lecz wskazują na zwierzęcą naturę ludzi (Przesmycki 1967, s. 213). Ironia, która w nich pobrzmiewa (tak jest np. w nawiązującym do przypowieści Voltaire'a utworze $O$ braminie; por. Bramin i matpa), ma swoje źródła w naznaczonym melancholią doświadczeniu upływającego czasu, w poczuciu nieuchronności zdarzeń. Bajki „nowego typu”, jak określił je Zenon Przesmycki w cytowanym na początku artykule z „Chimery” (Odrodzenie bajki), są więc prawdziwymi „opowieściami o życiu duszy”, ilustrują bowiem niepokoje i lęki człowieka tracącego oparcie w świecie; istoty, która „nie jest (nie jest gotowa) lecz się staje”, próbuje, często rozpaczliwie, odnaleźć w „pokawałkowanym świecie" swoje miejsce. Logos nowoczesności kształtowany przez artystów modernizmu ukazuje niekiedy ,janusowe oblicze” współczesnego świata, odsłania bowiem powolny proces erozji - dekonstrukcji podmiotowości, który rozpoczął się już w okresie romantyzmu. Mit postępu, kształtowany przez pozytywistyczną wiarę w naukę i moc rozumu, jedynie usankcjonował niepokoje związane z kryzysem tożsamości, powolnym zerwaniem relacji ze światem (procesy alienacji). Wzrost roli działań społecznych, utylitaryzm, praca społeczna stanowiły zaledwie protezy nowoczesnego istnienia, które miało zbudować praxis na podstawie sztuki i nowej roli artysty. W rezultacie jednak pojawiło się duszne uczucie zamknięcia, zewnętrznego więzienia ${ }^{12}$, które wchłonęły nurty artystyczne modernizmu. Nowoczesna sztuka nie funkcjonowała „na użytek” życia; życie miało naśladować sztukę. To ukierunkowanie refleksji estetycznej prowadziło w stronę autonomii, indywidualizmu. Przyczyniło się także do

12 Pojęcie wprowadzone przez Gastona Bachelarda. 
krytyki tradycyjnych norm semiotyczno-komunikatywnych, „kryzysu podmiotowości”13. Bohaterowie literaccy charakteryzowali się nadmierną autorefleksją, która prowadziła „na szczyty rozpaczy” (Wojda 1998, s. 209), do autodestrukcji indywidualizmu (warto przypomnieć zdanie Artura Rimbauda: „Ja - to ktoś inny") ${ }^{14}$.

Twórczość Jankowskiego interesująco oświetla aporie współczesności; pisarz nie odrzuca tradycji, wykorzystuje m.in. romantyczne antynomie czasu i przestrzeni, nadaje im nowe znaczenie, wpisując w kontekst egzystencjalnego dyskursu (por. Bajki o nieskończoności), który współtworzy jeden z ważniejszych nurtów modernizmu. Refleksja o istnieniu sytuuje się w strumieniu dysput o nowoczesności, które obejmują zarówno przyszłość, jak i teraźniejszość, nie dezawuują tradycji.

Utwory Jankowskiego odzwierciedlają nastroje epoki przełomów, prezentują obraz człowieka współczesnego, „człowieka momentu”, który szuka oparcia w świecie, nie znajduje go jednak. Nowoczesność nie tylko jawi się w literackim uniwersum jako motyw przewodni, lecz także wyznacza nowe perspektywy, ,przełomy” tak ważne m.in. dla dyskursu estetycznego. Bajka zajmuje w nim istotne miejsce. Jest opowieścią o początku i końcu, o losie, uwikłaniu w świat, pogrążeniu w chaosie. Nowoczesność ujawnia się także w narracji, która nie tylko „wprowadza” perspektywę podmiotowości (tożsamości, jej braku, konstrukcji i dekonstruowania Ja mówiącego), lecz także wskazuje na konstytutywną rolę mowy, jej żywiołowość, „inicjuje” niejako postawę adresata - słuchacza (rzeczywistego lub mimowolnego), jest więc zakorzeniona w świecie zewnętrznym. Narracja odnosi się także do sfery wewnętrznej (współobecność lub opozycyjność wnętrza i zewnętrza stanowi ważny element procesu indywiduacji podmiotu). Mowa odzwierciedla istotne antynomie współczesności, które w utworach Jankowskiego przyjmują postać opozycji (lub supozycji współistnienia podobieństw) wnętrza atomu i zewnętrza świata (Bajki o nieskończoności), co stanowi interesujące nawiązanie do relacji: dusza człowieka i dusza świata. Refleksja o nieskończoności kształtuje się w perspektywie różnic i podobieństw, w zestawieniu dwóch perspektyw: ogromu i małości, które nigdy nie są ostateczne, skończone, w pełni wymierne. Człowiek jawi się jako istota niegotowa - zarówno w perspektywie ogromu świata, jak i w wymiarze duchowym, który ostatecznie, jak postulował m.in. Charles Baudelaire w wierszu Oddźwięki, jest prawdziwym światem. W bajkach

${ }^{13}$ Zagadnienie to rozważa m.in. Astradur Eysteinsson (por. Wojda 1998, s. 209).

${ }^{14}$ Paul de Man (2000, s. 67) traktował nowoczesność jako konieczny czynnik rozwoju, który zostaje wchłonięty przez proces historii. 
dominuje temat duszy. W Historiach niezwyktych jej natura ujawnia się w sytuacjach granicznych: w doświadczeniu bliskości śmierci, w przeżyciu miłości. „Kraj ducha” jest w dużej mierze nasycony pragnieniami, tęsknotami za nieskończonością, prawdziwym istnieniem (bo to „tu i teraz” okazuje się złudne). Utwory Jankowskiego mają najczęściej palimpsestową strukturę, kształtują ją rzeczywiste i symboliczne obrazy: odbity w lustrze „obraz ducha”, nastrojowa, pełna przeczuleń aura wiosennej nocy (niczym opowieść Szeherezady), spotkanie towarzystwa spirytystycznego. Zestawienie różnych „tekstów” - opowieści tworzy nowy, interesujący obraz współczesnego świata, uzależniony od strategii „narratora”, od punktu widzenia zasłuchanego w opowieść odbiorcy.

\section{Bibliografia}

\section{Literatura podmiotu}

Jankowski J. (1928), Historie niezwykłe, Warszawa.

Jankowski J., Atom, w: Bajki o nieskończoności. Poezja ilości, rkps b.s. (uid repozytorium), nr 15913171.

Jankowski J., Bajki $i$ wiersze, Archiwum Józefa Jankowskiego BN, rkps 5048 II.

Jankowski J., Diabet albo jak soltys zbawiat swoja dusze, w: J. Jankowski (1928), Historie niezwykte, Warszawa.

Jankowski J., Miłość gwiazdy, BN rkps 5063 III.

Jankowski J., Piękna bajka o kanałach Marsa, rkps, Archiwum Józefa Jankowskiego, POLONA [uid repozytorium 15913171].

Jankowski J., Tajemnica księżycowa, w: J. Jankowski (1928), Historie niezwykłe, Warszawa.

\section{Literatura przedmiotu}

Blake W. (1992), Proroctwa niewinności, w: „Z Toba, więc ze Wszystkim”. 222 arcydzieła angielskiej i amerykańskiej liryki religijnej, wybór i przekł. S. Barańczak, Kraków.

Czabanowska-Wróbel A. (1996), Baśń w literaturze Młodej Polski, Kraków.

Foucault M. (2006), Stowa i rzeczy. Archeologia nauk humanistycznych, Gdańsk.

Głowiński M. (1997), Ekspresja i empatia. Studia o młodopolskiej krytyce literackiej, Kraków.

Krajewski R. (2009), Nieskończoność, w: Encyklopedia Katolicka, t.13, Lublin.

Mallarme S. (1900), Okna, przeł. Z. Przesmycki, „Życie” nr 1.

Man P. de (2000), Ideologia estetyczna, przeł. A. Przybysławski, Warszawa. 
Miciński T. (1995), Reinkarnacja, w: tegoż, W mroku gwiazd, oprac. i wstęp W. Gutowski, Kraków.

Nycz R. (1998), ,Wyrażanie niewyrażalnego” w literaturze nowoczesnej (wybrane zagadnienia), w: Literatura wobec niewyrażalnego, red. W. Bolecki, E. Kuźma, Warszawa.

Osiński Z. (1998), Jerzy Grotowski. Źródła, inspiracje, konteksty, Gdańsk.

Pascal B. (b.r.), Myśli, przeł. T. Boy-Żeleński, Warszawa.

Podraza-Kwiatkowska M. (red.) (1977), Programy i dyskusje literackie epoki Młodej Polski, Warszawa.

Poe E.A. (2009), Ligeja, w: Opowiadania, przeł. M. Kulak, P. Dobrowolski, B. Leśmian, Warszawa.

Poulet G. (1974), Pascal, w: Antologia współczesnej krytyki literackiej we Francji, oprac. W. Karpiński, Warszawa.

Poulet G. (1977), Metamorfozy czasu. Szkice krytyczne, wstęp i wybór J. Błoński, M. Głowiński, Warszawa.

Przesmycki Z. (1967), Odrodzenie bajki, w: tegoż, Wybór pism krytycznych. Publicystyka literacka $i$ artystyczna z lat 1901-1907, oprac. E. Korzeniowska, t. 2, Kraków.

Przybyszewski S. (1977), O nowa sztuke, w: Programy i dyskusje literackie epoki Młodej Polski, red. M. Podraza-Kwiatkowska, Warszawa.

Renaut A. (2003), Era jednostki. Przyczynek do historii podmiotowości, przeł. D. Leszczyński, Wrocław.

Ribot T. (1901), Wyobrażnia twórcza, przekład nieznany, Warszawa.

Rilke R.M. (1898), O sztuce, „Ver Sacrum” t. 1 (cyt. za: Grabska E. (oprac.) (1971), Moderniści o sztuce, Warszawa).

Schelling F.W.J. (1983), Filozofia sztuki, przeł. K. Krzemieniowa, Warszawa.

Wojda D. (1998), Projekt krytyczny modernizmu Astradura Eysteinssona, w: Odkrywanie modernizmu, red. R. Nycz, Kraków.

Zdziechowski M. (1977), Płazy a ptaki, Programy i dyskusje literackie epoki Młodej Polski, red. M. Podraza-Kwiatkowska, Warszawa.

\section{Streszczenie}

\section{„Duch nowoczesności” - w kręgu bajek Józefa Jankowskiego}

Artykuł prezentuje różnorodność bajek Józefa Jankowskiego, który nadaje temu gatunkowi nowoczesne znaczenie. Bajki są bowiem opowieściami o marzeniu, nieskończoności, porządkują chaos świata, interpretują trudną rzeczywistość. Analiza i interpretacja utworów pozwala zadać pytanie o definicję nowoczesności. Jankowski pojmował ją jako istotny element dyskursu estetycznego. 
Nowoczesność była dla modernistów ważnym wyzwaniem. Postrzegali ją oni jako podstawę światopoglądu, którego etapy rozwoju wyznaczała zaś sztuka.

Słowa kluczowe: modernizm, nowoczesność, Józef Jankowski, bajka literacka, bajka ludowa, nieskończoność, melancholia

\section{Summary \\ "The spirit of modernity" - in the circle of fairy tales by Józef Jankowski}

The article presents the variety of fairy tales by Józef Jankowski, which gives this genre a modern meaning. Therefore, fairy tales are stories about a dream, infinity, they organize the chaos of the world, they interpret difficult reality. Analysis and interpretation of works allows us to ask a question about the definition of modernity. Jankowski understood it as an essential element of the aesthetic discourse. Modernity was an important challenge for modernists. They saw it as the basis of the worldview, and art marked the stages of its development.

Keywords: modernism, modernity, Józef Jankowski, literary fairy tale, folk tale, infinity, melancholy 